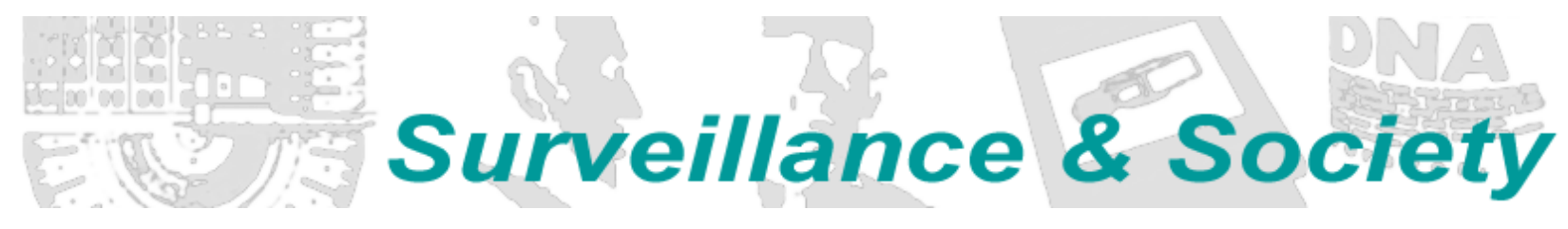
\title{
\begin{tabular}{l|l} 
Political Economy and the Australian Government's \\
CCTV Programme: An Exploration of State-
\end{tabular} Article Sponsored Street Cameras and the Cultivation of Consent and Business in Local Communities
}

\section{Robert Carr}

Western Sydney University, Australia.

R.Carr@westernsydney.edu.au

\begin{abstract}
This article explores the political economy of Closed-Circuit Television (CCTV) in Australia, providing new insights into the relationship between government policy and its economic implications. I have rationalised state-sponsored street cameras as a component in the cultivation of consent between the state and local communities; a mechanism for government to facilitate the flow of public funds to business through arrangements that are virtually unchecked and non-evidence based; a mechanism for government to facilitate profitable opportunities in and beyond the security technologies industry; and, a mechanism to normalise hegemonic social and political relations at the level of discourse. This article explores how government has assisted growth in the security industry in Australia. I draw on a case study about Kiama Municipal Council's decision in 2014 to accept funding from the Abbott Government to install CCTV cameras through the Safer Streets Programme. This is despite historically low crime rates in Kiama and an inability to demonstrate broad support for the programme in the local community. This study reveals how politicians have cultivated support for CCTV at the local level and pressured councils to install these systems despite a lack of evidence they reduce, deter or prevent crime. Examined is how the footage captured on local council CCTV has been distributed and its meanings mediated by political and commercial groups. I argue that the politics of CCTV dissemination in Australia is entwined with the imperatives of electoral success and commercial opportunity-a coalescent relationship evident in the Safer Streets Programme. Furthermore, the efficacy of CCTV as an electoral tool in Australia is explained via the proposition that street cameras perform a central role in the discourses and political economy of the state.
\end{abstract}

\section{Introduction}

Initiated by the Liberal-Nationals Coalition led by Prime Minister Tony Abbott, the Australian Government's 'Safer Streets' street camera funding policy is underscored by opportunities for political and commercial gain. In this article I refer to a case study on Kiama's street surveillance programme, which is supported by Safer Streets funding, to unpack a paradoxical rationale underpinning the political economy of local council Closed-Circuit Television (CCTV) programmes - one that ignores how public surveillance schemes internationally are yet to produce any substantial evidence that they are effective in terms of the oft-stated purposes of reducing, preventing and deterring crime (Carr 2014a). By doing so I raise unexplored questions about the relationship between government street camera policies and their economic implications. 


\section{Bronwyn Bishop smiles for the cameras in Gilmore}

By ROBERT CRAWFORD Aug. 29, 2013, 4:05 a.m.

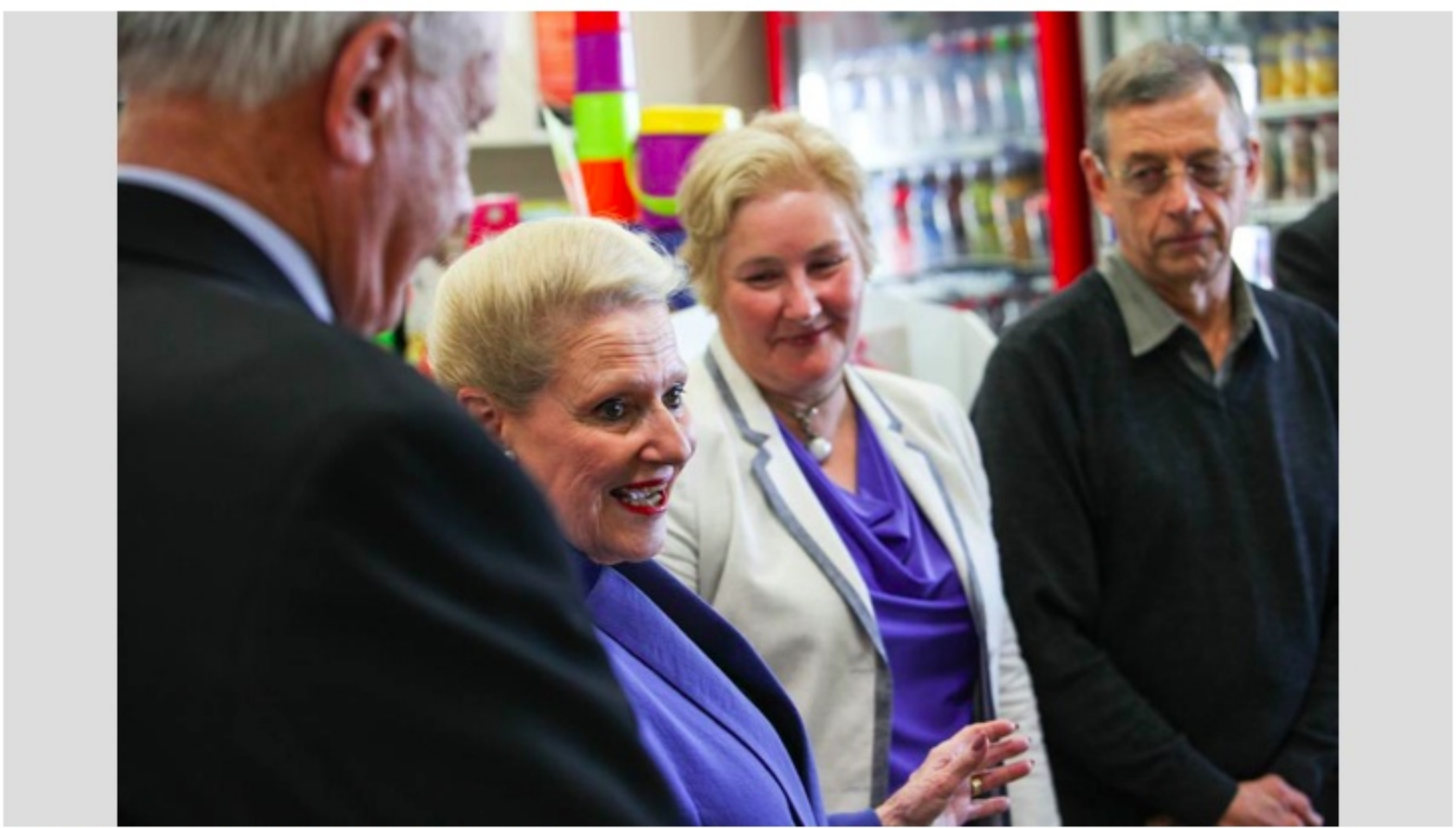

Bronwyn Bishop says that if the Coalition wins the election, it will provide funding for CCTV cameras in Gilmore, Shoalhaven and Klama. Picture: DYLAN ROBINSON

Image 1: Ann Sudmalis (centre-right) campaigning for election in Gilmore with Bronwyn Bishop MP, from The Illawarra Mercury 29th August 2013

Kiama is a small tourist town on the South Coast of New South Wales (NSW), Australia in the Illawarra region. The town has a history of very low crime rates (NSWBOCSAR 2014). Liberal Party Members of Parliament (MPs) representing the state electorate of Kiama and the federal electorate of Gilmore-Gareth Ward and Ann Sudmalis respectively - have propagated a strong political message that crime in Kiama's Central Business District (CBD) would be significantly hampered by the installation of CCTV (Ward 2014; Sudmalis 2014). Their enthusiasm has been bolstered by the delivery of Safer Streets funding for the installation of a CCTV network in Kiama's CBD in May 2014. CCTV funding was first provided by the Coalition Government led by John Howard under its 'National Community Crime Prevention Programme' in 2004 (Australian Government 2012; Australian Government n.d.: b, c). Kiama's CCTV programme is among the latest local council surveillance schemes to emerge as a direct result of 'holy grail' (Taylor 2010) crime prevention promises made by politicians across Australia throughout the last decade.

Through the Safer Streets Programme the Abbott Government has made concerted efforts to cultivate community expectations of local councils to perform surveillance roles. The powerful anti-crime symbolism of surveillance technology is deeply incorporated into the discursive strategies adopted by Coalition politicians. The Australian Government's CCTV funding programme is rationalised as a policy for delivering public funds and commercial opportunities to the private sector in a way that is virtually unchecked and non-evidence based. News media has gained significant commercial opportunities from distributing footage captured on government funded CCTV. Politicians have worked to mediate the meanings affiliated with CCTV as well as the terms in which surveillance technology funding is provided to local councils. Such a strategy has provided politically exclusive opportunities for the Abbott Government to cultivate local community support and 'pork barrel' public funds. The politics of CCTV 
dissemination in Australia is entwined with the imperatives of electoral success and commercial opportunity - a coalescent relationship evident in the Safer Streets Programme. The efficacy of CCTV as an electoral tool in Australia is explained via the proposition that street cameras perform a central role in the discourses and political economy of the state.

\section{Surveillance and the 'Local' Context}

Exploring 'localised' conditions for the political economy of CCTV, this article is concerned with 'ground-level circulations' (Ball and Snider 2013: 6) and 'the imaginaries that wrap up the political process at the local level' (Galdon Clavell 2011: 524). It builds on Galdon Clavell's (2011: 523) research on Barcelona which explores 'what local dynamics can tell us about the specifics of the interaction between institutional settings, political processes, financial interests and social concerns'. The study adds to 'Gramscian' understandings of street surveillance schemes such as Coleman's research, centred on Liverpool, of the contribution of street cameras to legitimatising commercial interests in the reconfiguration of and meanings affixed to city spaces (Coleman 2013).

The proliferation of CCTV is often driven by politicians with intentions to acquire an electoral mandate. The language surrounding proponents of CCTV in the Illawarra context can be viewed as a discursive strategy for reproducing political power as well as being advantageous to commercial groups. This is not only in relation to the security technologies industry but also to unaffiliated commercial beneficiaries such as news media. Small businesses have been strongly motivated to seek the installation of street cameras at the expense of the taxpayer and ratepayer (Sudmalis 2014). The Abbott Government's policy to fund installations of the technology at public expense conveys the idea that government is 'doing something' about crime and 'incivility' and 'it is, therefore, an electoral tool' (Garland 2001; Galdon Clavell 2011: 525). The automated manner in which politicians commonly respond to business pressures, particularly in relation to perceptions of crime, indicates a widening gap between citizens and elected officials in terms of the latter's commitments to evidence-based community engagement. Such a scenario raises significant questions about the quality of public life and Australian democracy. Highlighting this point, recent federal election campaigns were described by political commentators as 'the worst in our modern history for the debased quality of political discourse' (Jones, cited in Cook 2014).

Scholars have explored strategic partnerships between government and corporate entities to enhance hegemonic 'preferred' perceptions of public space, and the marketability of those perceptions in ways that are aligned with desires for commercial expansion and political authority (Coleman 2013: 143). Similarly, Fussey (2007: 229) examines how the "process of CCTV installation-from conception to material implementation - is disrupted and mediated by a range of micro-level operations, obligations, processes, managerial concerns (particularly conflict resolution and resource issues), structures and agency, and the indirect influence of central government.' Researchers have studied how 'imageability' becomes a major selling point in the implementation of 'safe city' strategies within local economies heavily dependent on tourism; in such a scenario 'place-promotion can replace the original crime-control purpose' of street cameras (Koskela 2006: 168). Webster (2009: 10) elaborates how government CCTV policy can be viewed as a series of 'complex intertwined interactions between government, policy-makers, the media and other stakeholders, and that CCTV does not necessarily have to "work" if it meets other purposes.' Unexplored in scholarship are informal or implicit partnerships between government and business and the conditions in which public-owned CCTV footage is transferred to media. The commercial exploitation of CCTV footage by media has perhaps been an unintended consequence of publicly funded street cameras.

While state and federal governments continue to fund street camera initiatives, local councils have been the primary government user of CCTV (Victorian Law Reform Commission 2010: 34). Local council CCTV is limited by the separate jurisdictional powers of state and federal governments under the Commonwealth Constitution. The Privacy Act 1988 (Cth), though not specifically designed to regulate 
public place surveillance, requires Australian government and some private sector organisations to adhere to 'Australian Privacy Principles'. ${ }^{1}$ Local council street camera programmes are limited by a suite of state regulations ${ }^{2}$ and operating guidelines. The NSW Guidelines (NSW Attorney General's Department 2000), for instance, recommend local councils develop and implement oversight procedures for the operation of a street camera network in accordance with the state's privacy legislation. Meanwhile funding arrangements for local council CCTV are heavily under-scrutinised. While oversight on government spending is provided through the Office of the Commonwealth Auditor-General, this has not prevented the politicisation of taxpayer spending on street cameras. The Safer Streets Programme has been criticised for 'a lack of transparency over its guidelines, its selection criteria, and ultimately, over which projects were chosen’ (Kenny 2014b).

\section{Model of Analysis}

Scholarship has emphasised the need to examine "the political economy of surveillance and control in order to provide a comprehensive picture of the driving motives and ideas behind our increasingly surveilled societies' (Galdon Clavell 2011: 523). Most political economy research on surveillance has analysed the 'formal relationships between markets, technologies, policy and politics, leaving out a broader understanding of the motives and expectations that are taking shape alongside the increase of surveillance and control mechanisms' (Galdon Clavell 2011: 523). Surveillance scholarship has largely been "grounded in a broad view of the term "political economy" as one which concerns the interconnection of social, political and economic processes' (Ball and Snider 2013: 1). Scholars have emphasised, furthermore that, "[t]he notion that we can speak of "a" or "the" political economy of surveillance is a misnomer; in fact we must speak of political economies' (Pridmore 2013: 107). Lacking in Surveillance Studies are experimentations with a more structured model for the political economy of street cameras. Ideally such a model would build on methodological frameworks that are context specific (Germain 2013; Anderson and McAtamney 2011; Keval and Sasse 2010). It is necessary to limit the scope of the chosen case study in order to explore 'a form of surveillance that is temporal in nature, [and] contingent upon changes in daily practices of consumption and commercial interests' (Pridmore 2013: 107). The analytical model adopted in this article does not intend to provide a universal framework of analysis for researchers; rather, it is an experimental approach, deemed useful having surveyed the available accumulated evidence. Source material for the investigation incorporates news media coverage, federal and state government policies, minutes and reports from local councils, CCTV funding scheme guidelines, and media releases from and interviews with politicians. ${ }^{3}$ An exhaustive textual analysis of the available empirical sources has been undertaken concerning the implementation of the Safer Streets Programme. Moreover, discourse analysis has been undertaken of the language used by government, parliamentarians and media in relation to Safer Streets funding.

Incorporating such evidence has been useful for exploring intersections between surveillance and political economy within the nominated local and national contexts. Drawing on these parameters I conceptualise street cameras as:

\footnotetext{
1 'Australian Privacy Principles' cover the collection, use, disclosure and storage of personal information (Office of the Australian Information Commissioner 2015). These overarching national privacy protections are relevant considering local councils often operate street camera systems in partnership arrangements with major corporations - for example, the GPT Group (2015) and Stockland (2015) — and local business chambers (Carr 2014a).

2 In NSW, for instance, local council CCTV programs operate within the parameters of the Privacy and Personal Information Protection Act 1998 (NSW) (or PPIP Act), Workplace Surveillance Act 2005 (NSW), Security Industry Act 1997 (NSW), and Government information (Public Access) Act 2009 (NSW).

${ }^{3}$ Interviews were conducted as part of a separate exercise in news journalism, as per Carr (2014b).
} 
i. a component in the cultivation of stronger consensual relations between the Federal Government and local councils and their communities;

ii. a mechanism allowing government to facilitate the flow of public funds to private companies through arrangements that are virtually unchecked and non-evidence based;

iii. a mechanism through which government has facilitated profitable opportunities in and beyond the security technologies industry; and,

iv. a mechanism for reproducing political and social hegemony by working to normalise these relations at the level of discourse.

As a model of analysis these propositions provide opportunities to build on scholarship examining 'surveillance as an organizational control process, one that $[\ldots]$ perpetuates the interests and voices of certain actors, certain ways of seeing and doing, and weakens or silences others' (Ball and Snider 2013: 6). By identifying the four key themes for this model, I have sought to deepen scholarly understandings of how the surveillance-industrial complex spans global neo-liberal economics and interacts with the state. In this tradition scholars have 'tended to explain surveillance as a technology with social consequences' (Galdon Clavell 2011: 523) and the rise of 'surveillance societies' as emerging through a range of complex but dialectical military and corporate priorities (Lyon 2001; Ball and Snider 2013: 1-2). As Galdon Clavell (2013: 192) says: 'there are processes at work that contribute new elements to understanding videosurveillance proliferation'. These include factors of global appeal such as: inducing obedience; a growing tendency to rely on technical solutions for social problems; a business-led shift from the social prevention of crime to situational solutions to social problems; and, a strategy for removing disorder from places of spectacle and consumption (Galdon Clavell 2013: 192). Often overlooked is 'how all these global trends are ultimately negotiated at the local level, and how it is the local political configurations and reconfigurations, historical factors and internal dynamics of power that ultimately give shape to the specific uptake processes' (Galdon Clavell 2013: 192).

\section{Surveillance, Space and Power Relations}

Bentham's 'Panopticon' prison, with its centralised but random surveillance capacities, is often said to be mirrored in video surveillance; '[p]eople under surveillance are - as in the Panopticon- to be seen but to never know when or by whom; under control but without physical intervention' (Koskela 2003: 293). Foucault's (1980) exploration of the Panopticon is drawn on in scholarship to rationalise surveillance as an authoritative 'gaze' watching public space. He describes this process as '[a]n inspecting gaze, a gaze which each individual under its weight will end by interiorising to the point that he is his own overseer, each individual thus exercising this surveillance over, and against, himself. A superb formula: power exercised continuously and for what turns out to be a minimal cost' (Foucault 1980: 155). Foucault (1980) affirms that space is crucial in explaining power relations - not only to the exercise of power but in that power also creates a particular kind of space imbued with authoritative meanings and hegemonic implications that involve differentiating and organising subject populations (Koskela 2003: 292).

From this perspective surveillance is a platform for centralising power over the meanings and messaging attributed to surveillance systems (Haggerty and Ericson 2000). However, such a position overlooks dynamics that have emerged via contemporary surveillance practices. Haggerty and Ericson (2000) utilise the concept 'surveillant assemblages' to demarcate the increasing convergence of once discrete systems of surveillance. In doing so Haggerty and Ericson (2000: 606) affirm that recent technological advancements have led to the proliferation of information and data gathering techniques which operate to break the human body into a number of discrete signifying data flows that are "then reassembled in different locations as discrete and virtual "data doubles". The processes surrounding surveillant assemblage transform the purposes and hierarchies of surveillance, purportedly resulting in 'a partial democratization of surveillance hierarchies' (Hier 2003: 400). 
Hier (2003: 400) urges caution in considering the surveillant assemblage model; 'the problem derives from the fact that the fundamental object of contestation ... is the supposition that the impetus to surveillance comes ostensibly from above (variations on which take the form of the panoptic power of the state)'. Instead, Hier (2003: 400) states, the impetus for surveillance practices 'is not located in powerful social actors or elite bodies'; rather, 'considerable foundational support [for surveillance practices] derives from popular social grievances, various antagonisms directed at a variety of socially constituted risk groups from below, which come to secondarily culminate in the intensification of top-down regimes of surveillance.' A more complete understanding of contemporary surveillance systems 'must take seriously the social and cultural forces which give rise to, and sustain, assemblages' (Hier 2000: 401). By extension this infers rationalising the relationship between political economy and the cultivation of consent for public spending on street cameras.

\section{Political Economy, CCTV and the Coalition}

The Abbott Government allocated \$50 million towards CCTV schemes in the 2014-2015 Federal Budget. The government, led by Abbott's Coalition predecessor Prime Minister John Howard, also allocated \$65 million towards street cameras under national crime prevention schemes. CCTV funding has not been peculiar to the Coalition as Labor federal governments have also distributed funding for local council street cameras schemes. CCTV funding schemes have been a normative spending arrangement for both of the major parties. As one study explains, government support for street cameras is heavily tied to political opportunism; in Barcelona, 'politicians from the same party can be for or against CCTV depending on whether they sit in the government or the opposition in different cities' (Galdon Clavell 2013: 194).

The push by politicians to install CCTV in their electorates can be viewed as a deliberate attempt at mobilising 'the domains or entities to be governed: to govern one must act upon [a range of] forces, instrumentalize them in order to shape actions, processes and outcomes in desired directions' (Rose 1999: 4). This is particularly the case with regards to political parties campaigning to uphold the interests of business. CCTV has played a significant role in the marketing of public areas as 'risk-free' environments designed to attract consumers, tourists and business investment (McCahill 2002: 12; Wilson and Sutton 2003: 19). As Coleman (2004: 204) states: 'numerous references can be found to the idealised neoliberal cityscape of service-led economics, consumption and tourism that sits alongside promises of clean and safer streets'.

Yet to be outlined within Surveillance Studies from a political economy perspective is a sufficient understanding of the monetary value of trading in public-funded surveillance technologies and the profits resulting from footage they produce. As noted, a component of the model drawn on in this article to explain the political economy of government funded CCTV in Australia involves identifying links between government expenditure on street cameras and commercial opportunities. Table 1 reveals that expenditure on private security in Australia between 2012 and 2013 was almost \$5 billion (ASIAL 2014). Furthermore, Table 1 indicates that national spending on security devices, installation and monitoring is worth approximately $\$ 2.3$ billion to the private security sector. This is marginally less than the amount spent on 'manpower' which includes roles performed by people rather than technology including those working as security guards. 


\begin{tabular}{|c|c|}
\hline $\begin{array}{l}\text { 'Manpower' (including customer } \\
\text { service/concierge, loss prevention/retail } \\
\text { security, corporate risk, investigation services, } \\
\text { cash management, armed escorts, ATM } \\
\text { servicing, event security, crowd control, } \\
\text { critical infrastructure protection, aviation } \\
\text { /maritime security, mobile patrols/alarm } \\
\text { response.) }\end{array}$ & $\$ 2.514$ billion \\
\hline $\begin{array}{l}\text { Hardware, electronics and equipment } \\
\text { (including access control, biometrics, alarms, } \\
\text { CCTV) }\end{array}$ & $\$ 760$ million \\
\hline Installation & $\$ 810$ million \\
\hline Monitoring & $\$ 390$ million \\
\hline Other & \$383 million \\
\hline Grand Total & $\$ 4.857$ billion \\
\hline
\end{tabular}

Table 1: Estimated expenditure on private security in Australia, 2012-2013 (ASIAL 2014)4

Australian Security Magazine claims: 'Technology is also having a significant impact on the security industry; in a positive way. If you keep up-to-date with market forecasts, the electronic security market is forecast to experience double digit growth until 2020 and beyond' (Percy-Dove 2014). The publication concluded: 'The commercial argument for the use of security technologies over more traditional security measures has never been more valid' (Percy-Dove 2014). Certainly, in the absence of any meaningful mechanisms for reporting and evidence-based evaluation, suppliers of technology and security tech consultants are major beneficiaries from state-funded programmes to roll out security technologies. Local councils, faced with increasing expectations to accept funding from state and federal governments to install CCTV, are a major contributor to the industry's growth. Business chambers are asking the taxpayer to finance the set-up and then the ratepayer to fund ongoing costs for CCTV (Carr 2014b). By sequestering \$50 million from the public purse, the Safer Streets Programme is stimulating demand for the security tech industry and the public is transformed into a guaranteed future customer as running costs need to be met (Carr 2014b).

As a point of comparison, in her case study on Barcelona Galdon Clavell says (2011) it is difficult to find big economic interests lobbying public bodies to buy video-surveillance cameras, and this is probably because the CCTV industry is highly atomised with usually small companies contracted to install security devices. Similarly, in Australia there is little evidence revealing how commercial operators lobby government with the intended effect of generating growth in commercial benefits to CCTV suppliers, consulting and operators. Galdon Clavell raises a pertinent question about the political economy of CCTV; 'if it is impossible to find public or private actors that are passionate about CCTV, and nobody is making tons of money with it, why does it seem so difficult to stop or question the proliferation of surveillance technology?' (Galdon Clavell 2011: 525) Arguably there is no explicit lobbying of politicians by commercial operators because their respective aims are congruent. These mutual interests are intertwined within hegemonic discourses of 'civility' in which certain behaviours have been criminalised and labelled

\footnotetext{
${ }^{4}$ Figures provided are an estimate only, according to ASIAL (2014).
} 
as 'anti-social'. In such a political context, '[t]he need to impose "proper behaviour" and sanction deviance is the discourse used to justify and legitimize the need to control what people do in open, public space through the electronic lens - as well as an increased police presence and powers' (Galdon Clavell 2011: 525).

As Galdon Clavell (2011: 525) argues: 'The discourse around civility and surveillance, which effectively make up the broader security discourse at the local level, is not only a way to sell political alternatives to the electorate, but also a marketing tool used by the city both to fulfill the demands of the corporate sector and to compete at the global level.' Coaffee and Rogers (2008: 205) similarly describe recent developments in place branding practices internationally as intended to minimise 'reputational risk' while affirming reputational 'resilience'; in doing so, 'security is becoming one of many key selling points in the practice of city branding ... [it is] utilised by governance regimes to promote and brand particular locales as safe, secure and resilient to attack' (Coaffee and Rogers 2008: 205). One prediction is that '[t]he resulting picture will probably be one of power, uncritical policy-transfer, fear and contradiction. Not pretty, but maybe useful in terms of identifying weak links in the policy chain' (Galdon Clavell 2011: 526).

Throughout the remainder of this article, I explore similar implications with respect to uncritical policytransfer and how the Safer Streets scheme incorporates political and business interests. These implications include the notion that in Australia government CCTV primarily services the desire to 'feel safe', or the 'fear of crime', and the economic motivation to improve 'perceptions of safety' at the expense of more objective criteria for funding and evaluating street camera schemes (Carr 2014a, 2014b; Fussey 2004: 260). Also considered is the political implication that Safer Streets funding was made available only by invitation to nominated councils for the first round of funding. The programme provided the Abbott Government with opportunities to cultivate grassroots support — or at least a perception of it — by requiring local councils to ceremoniously 'accept' offers of funding. Politicians have cultivated this support by organising publicity, petitions and mobilising business chambers with 'no strings' carrots of public subsidies (Carr 2014a, 2014b). These implications are explored further below in a case study concerning Kiama Council's CCTV network and an analysis of how decisions to allocate funds via the Safer Streets Programme have been determined.

\section{Kiama's Street Camera Programme}

\section{i. About Kiama and Local Crime Rates}

Kiama municipality's crime rates in public spaces are well below the state average. Data collected by the NSW Bureau of Crime Statistics and Research (NSWBOCSAR 2014) states that non-domestic violence and theft has been stable in Kiama between 2011 and 2013. The municipality is ranked $129^{\text {th }}$ in NSW for non-domestic violence out of 141 local government areas with populations greater than 3,000 and there were just 40 incidences in 2013. Malicious damage to property has risen by 55 per cent per year over the last two years with 134 incidences in 2013. The upward trend, however, is still lower than the 2010 rate which was 152 incidences and which dropped to 86 incidences in 2012. These trends have seen Kiama Local Government Area (LGA) ranked $119^{\text {th }}$ out of 141 councils in NSW for malicious damage to property.

Crime levels in Kiama are negligible and crime appears to have been managed effectively prior to the installation of street cameras as evidenced in statements by the local police command (Crabb 2014b). Police statements in the media indicate there had been no need for increased security vigilance on the main thoroughfare (Terralong Street). Superintendent Wayne Starling stated: 'In Kiama, statistics are generally so low, numbers-wise, any offence seriously impacts on the percentages' (Crabb 2014b). Starling 'also noted that incidents, such as three malicious damages on April 14-15 [2014] in Shoalhaven/Terralong and Terralong/Manning streets, were rare occurrences' (Crabb 2014b). The detail in 
Kiama Council's plans contradict Starling's relaxed outlook on the prevalence of crime for the LGA; paradoxically, most of the new CCTV cameras are to be installed along Terralong and Manning streets according to Kiama Council's plans (Kiama Municipal Council 2014; see Image 2). Fourteen street cameras have been installed thus far though the initial plans involved the installation of twenty. There is also likely to be an expansion of the street camera network to the nearby town of Gerringong during Stage 3 (out of 3 stages) (Hall 2015).

\section{Approximate new camera locations.}

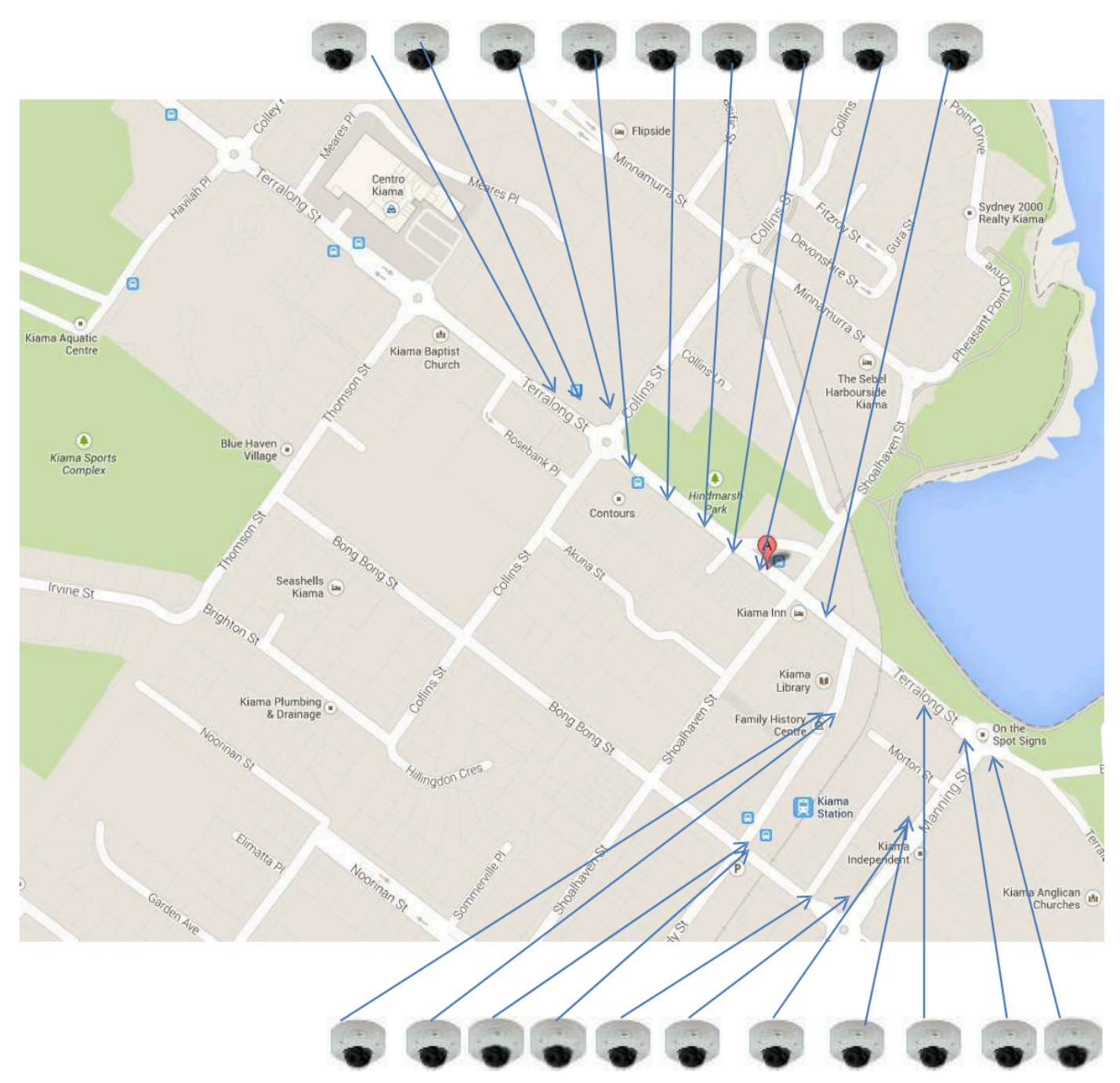

Image 2: Proposed locations of CCTV cameras in Kiama (Kiama Municipal Council 2014) 


\section{Kiama CCTV switch on slated for March}

By DAVID HALL Feb. 17, 2015, 5:30 p.m.

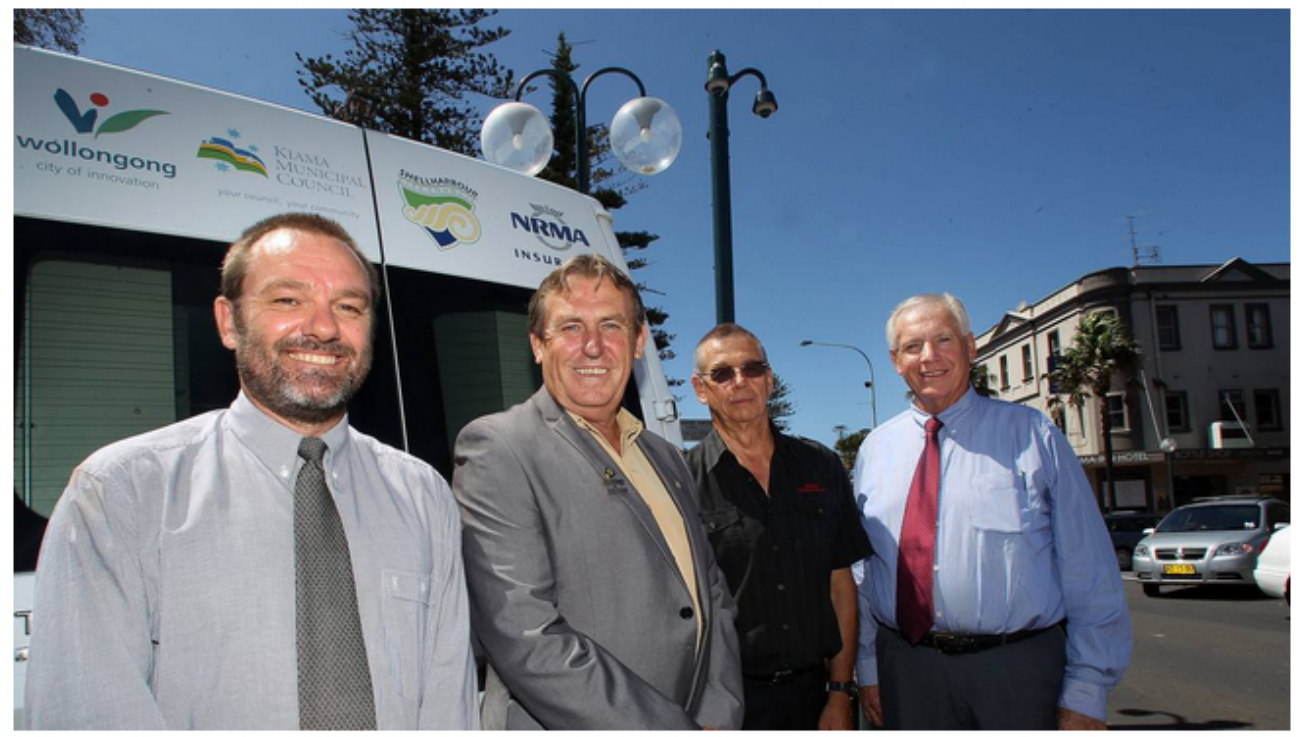

CCTV cameras have been installed in Kiama (from left) Kiama Council's Nick Guggisberg, councillor Dennis Seage, business owner Bruce Johnstone and mayor Brian Petschler. Picture: DAVID HALL

Image 3: Kiama Council officials promoting the installation of new street cameras at the Old Fire Station. Photograph published in the Kiama Independent, 17th February 2015.

The installation of Kiama's CCTV system was planned for mid-2014 though the system was not activated until early 2015. At the time of writing Stage 1 of Kiama Council's street camera program had been implemented (Hall 2015). Kiama is a renowned visitor destination promoted by tourism bodies as a picturesque coastal holiday town with its pristine coastline and heritage listed treasures (Visit NSW 2014; Kiama Tourism 2012). The nationally heritage-listed post office (Australian Heritage Database 2014) resides within the planned surveillance zone though cameras are yet to be erected in this locale. Street cameras have been installed in view of Kiama's 'Law and Order' heritage trail featuring a colonial-era courthouse, police station and police residence as well as a monument dedicated to libertarian British 'prisoner of conscience' George Weightman. The cameras also watch over the space occupied by the iconic 'Daisy the Cow' (Arnold 2014a) at the Old Fire Station across from the Kiama Inn Hotel (Hall 2015; see Image 3). ${ }^{5}$

As street cameras emerge as a normative feature of urban redesign 'Surveillance becomes more subtle and intense, fusing material urban space and cyberspace' (Koskela 2003: 292). Scholars have deliberated beneficial implications delivered through surveillance technologies such as public space 'web cams' pending that these are decentralised and operated directly by members of the public (Knight 2000; Koskela 2006). Drawing on surveillance more metaphorically, Vaz and Bruno (2003) elaborate how a public culture of 'self-surveillance' cultivates public demand to monitor public health risks and challenge corporate malpractices.

More skeptical perspectives affirm that the presence of government-operated surveillance cameras changes the aesthetic of public space and symbolises unequal social relations: "A surveillance camera represents total one-way-ness of the gaze by making it impossible to look back. There is no "mutual"

${ }^{5}$ There are a further two privately operated CCTV cameras across from this location surveilling the taxi rank and at least several private shopfronts featured noticeable street cameras along the main CBD thoroughfare of Terralong Street. 
gaze... Its objects are constantly seen but with no possibility to "respond" or "oppose" the gaze' (Koskela 2006: 175). A divide is created in that community members are able to gaze on the physical presence of the cameras but never to those behind the panoptical lens. The visibility of CCTV cameras placed upon poles at regular intervals also provides opportunities to make us more aware of the potential for crime and encourages the community to grow more suspicious. CCTV has increased suspicion and anxieties within communities particularly when surveillance programmes are established within ethnically diverse and poorer communities and in schools (Taylor 2011: 12; Coleman 2004: 200; Hasselberg 2014).

By contrast, Kiama's CCTV programme reflects a recent shift in Australia in the use of traditional street camera locations away from targeted demographic populations (for example, inner-city communities) towards a more blanketed approach aimed at countering potential crimes committed by all users of public space. This shift is reflected in the expansion of state-sponsored CCTV into low-urban density areas evident not only in Kiama but also comparable small towns such as Byron Bay on the northern coast of NSW (Byron Shire Council 2015). Kiama's street camera programme further appears to be much more broadly positioned and promoted to produce safer spaces for business operation within the lexicon of corporate risk aversion and business resilience practices (Coaffee and Rogers 2008).
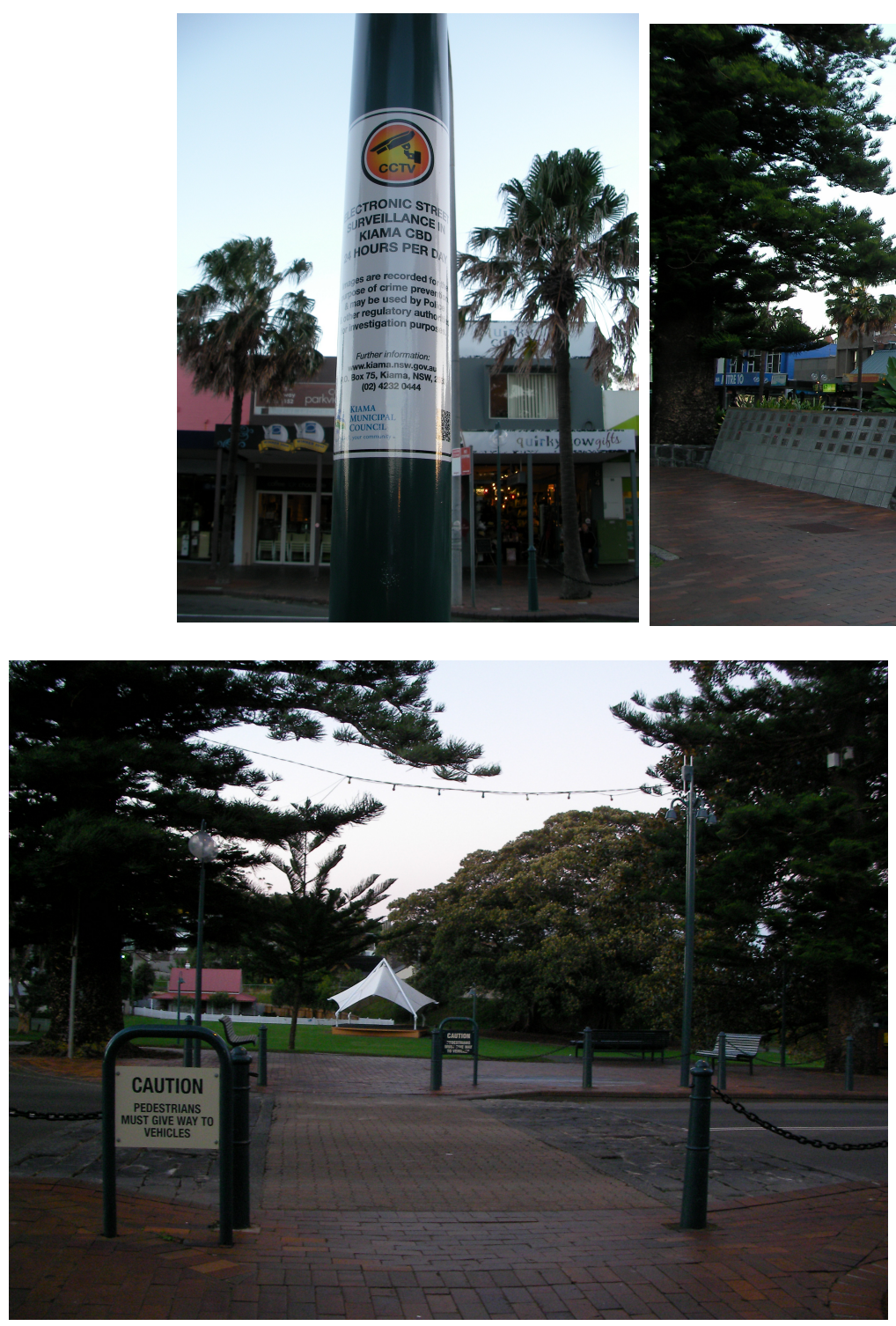

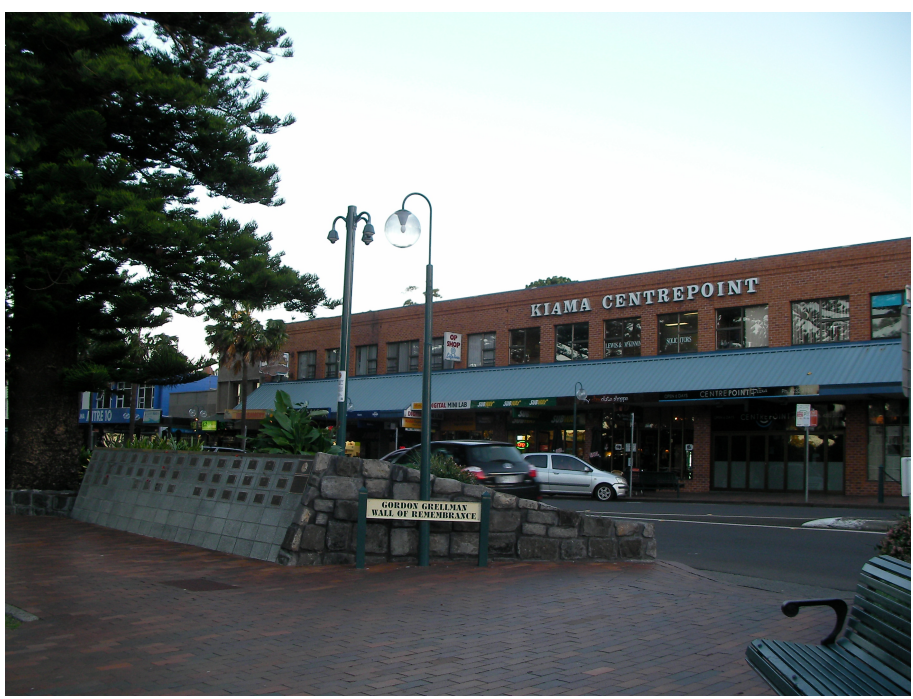

Images 4, 5 and 6: Several of Kiama's newly installed street cameras/poles and signage on Terralong Street, which appear to be intended to blend with the tree-lined footpath and park.

Photographs by R. Carr, $8^{\text {th }}$ May 2015. 
During Stage 1 of Kiama Council's street camera programme five poles have been erected along Terralong Street. Atop four of these sit three small dome cameras, with another pole host to one small dome camera and one larger rectangular unit. Each camera and pole is coated dark-green and positioned on or alongside the pedestrian path, granting opportunity to pan across the road towards Terralong Street business fronts. The public footpath skirted by Kiama's grass parkland and trees accommodates the cameras/poles rather than space immediately occupied by business fronts. The dark-green colour of the cameras/poles appears to have been intended to blend with the tree-lined pathway and grass strip, though they are close enough to the street to be noticed as are numerous large white placards advertising that CCTV is in operation (see Images $4-6$ ). ${ }^{6}$

\section{ii. Cost-Shifting: Public Funds for Private Business Security}

Despite very low crime rates, in May 2014 Kiama Council was granted \$150,000 from the Federal Government to establish a CCTV network. Federal funding was provided in conjunction with a further $\$ 50,000$ from the NSW State Government and Kiama Council will spend $\$ 80,000$ on the programme. Media reports (Crabb 2014a) and statements by Sudmalis (2014) and Ward (2014) indicate that local politicians anticipate significant benefits to business following the rollout of CCTV in Kiama. Sudmalis insisted there would be benefits to local taxi drivers 'here in Kiama because you've had hold-ups here, you've had vandalism near the taxi rank and you've had potential robberies near the taxi rank' (Cetinski 2013). According to Sudmalis the business sector has been the main lobbying force driving the installation of CCTV in Kiama (Cetinski 2013). The public has provided funding to protect private businesses from potential crime. These circumstances provide clear evidence of cost shifting from the private to the public sector when businesses seek to become the primary beneficiaries of surveillance schemes. The cost of operating camera systems has been exorbitant and unforeseen by councils across Australia; at one local council the federal government has paid approximately $\$ 83,000$ per camera while local councils were paying up to $\$ 600,000$ per annum out of their own budgets to keep a CCTV system operational (Carr 2014a). Police are yet to provide any funding towards the upkeep of CCTV systems installed by local councils (Carr 2014a). Such a scenario raises questions about the extent to which local governments ought to be responsible for maintaining security for private businesses.

\section{iii. Community Engagement}

Kiama Council propagated that it has 'strong support' from the community for CCTV in its CBD, a claim based on a total of 37 surveys completed by community members (Crabb 2014a). Kiama's population stands at around 20,000 (IRIS 2013), which makes the survey sample representative of just 0.185 per cent of local residents. As a point of comparison, other local councils state 10 per cent is a 'representative sample' for community engagement survey results (Sunshine Coast Council, 2014). Crabb (2014a) noted: 'Five more respondents emailed feedback. Of the respondents, 30 (72\%) supported the installation of CCTV and 11 respondents (26\%) were against it. Also, 32 respondents indicated they would like to see other areas of Kiama LGA covered by CCTV, and 14 said they didn't see the need for further areas to be covered.'

Crabb (2014a) continued: 'Those opposed to CCTV raised privacy issues, said CCTV was ineffective, preferred deploying more police, said CCTV was not cost effective, or that the level of crime did not

\footnotetext{
${ }^{6}$ The location of each camera/pole is as follows, successively West to East along Terralong Street: at the CBD's entry point on Collins Street at the prominent war veterans Memorial Arch (there are two poles/five cameras on this corner); at a pedestrian crossing about halfway along the CBD strip adjacent to a local bank; on the corner of Shoalhaven Street in front of the Old Fire Station surveilling the space occupied by the iconic 'Daisy the Cow' (Arnold 2014a); and, next to the train bridge on Railway Parade across from the Weightman monument. Another pole has been erected on Railway Pde outside the Kiama Council Library, though it is concealed in plastic sheeting and no cameras have been installed. No street camera poles have been installed as yet at the initially proposed CCTV locations along Manning Street and the entry to Kiama train station (as per Image 2).
} 
justify the cost'. There were no questions raised publicly about the small survey respondent size or the quality of community engagement surrounding the CCTV survey. A poll (Arnold 2014b) conducted by the local media asked community members: 'Do you feel safer walking in a business district which has CCTV cameras?' Seventy three per cent of respondents voted 'yes'. The media poll offers little useful information in terms of mirroring the public's understanding of the social, political and financial implications of operating a CCTV network. It does, however, lend to creating a perception of public acceptance for CCTV as a highly desirable crime prevention strategy. The poll offered no answer options other than CCTV pertaining to what could make communities safer such as improved street lighting, increased traffic and a greater number of police officers.

\section{iv. 'Cameras for Your Vote': The 2013 Elections and the Cultivation of Kiama's Crime Panic}

Politicians and news media have ignored the significance of crime trends and the fact that Kiama enjoys some of the lowest crime rates among all NSW local government areas. Despite these figures Sudmalis promoted CCTV funding as a core election promise in 2013 when she contested the federal seat of Gilmore. During her 2013 election campaign Sudmalis made a public pledge to Kiama residents for CCTV funding, standing alongside high profile federal Coalition MP Bronwyn Bishop. As reported (Cetinski 2013):

The first election funding commitment for Kiama came in the form of CCTV cameras, when opposition state spokeswoman Bronwyn Bishop visited last Wednesday. Meeting [...] with Liberal candidate for Gilmore Ann Sudmalis, Ms Bishop announced \$150,000, to be given to Kiama Municipal Council provided the Coalition was elected... Ms Sudmalis said people had to vote for her to receive the funding.

These electoral promises tap into an existing electoral climate-one primed by moral panic following highly visible instances of crime and the opportunities this provides for media savvy politicians. Politicians frequently refer to Jill Meagher's murder in Melbourne in 2012 to legitimate calls for increasing CCTV in public spaces (Carr 2014a). The murder case was widely covered by Australian news media, which often replayed CCTV footage captured by a private store depicting Meagher's final movements before her abduction. Seemingly on cue, the Meagher case was highlighted by the Member for Kiama to legitimate his argument for why Kiama needed CCTV (Ward 2014), even though it was not publicly owned CCTV that enabled police to apprehend the attacker. According to police documents submitted to court it was hi-tech police work, including mobile phone tracking and tollway data analysis, that provided the crucial breakthrough in the hunt for Meagher's attacker (Anderson 2013).

The Safer Streets Programme is firmly situated within this populist meta-narrative. Promoting the delivery of Safer Streets funding to Ryde City Council in July 2014, the Liberal MP for Bennelong John Alexander informed media: 'Statistics indicate that the installation of CCTV cameras helps reduce crime rates' (Carr 2014b). The Saturday Paper describes how: 'Asked for proof, his office provided two papers containing conclusions contrary to his claim. A 2009 Australian Institute of Criminology document states that there is 'ambiguous evidence surrounding its [CCTV's] effectiveness in preventing and reducing crime'. The second, a 2001 conference paper, says 'there is actually little evidence as yet of the success of CCTV to combat or deter crime'. But Alexander remains adamant: 'No one would question that CCTV reduces crime'. The Jill Meagher murder case [...] made clear that 'CCTV has played such an important role in catching criminals', he said (Carr 2014b).

The Member for Kiama similarly worked to raise expectations of Shoalhaven City Council as a Councillor and Deputy Mayor between 2004 and 2010. He repeatedly derided critics of his desires to install CCTV in Nowra CBD, particularly privacy campaigner Adam Bonner who challenged the legality of Shoalhaven Council to install CCTV in the Nowra CBD. Bonner won a legal challenge in the Administrative 
Decisions Tribunal in 2013 that saw Shoalhaven Council's CCTV cameras temporarily switched off. In response Ward expressed outrage stating: 'Mr Bonner should be apologising to the Shoalhaven for putting business and residents at risk' (Arnold 2013). Evidently Ward's intention in facilitating the rollout of street cameras in Kiama can be viewed as an extension of a long-term strategy to cultivate political support and public notoriety for his electoral agenda.

\section{v. Evidence-Based Research Labelled 'Minority'}

Scholarly analysis has been labelled a 'minority' opinion by Sudmalis who also claims those who support her efforts to fund CCTV in Kiama are the 'quiet majority' (Sudmalis 2014). The degrading of evidencebased research by politicians is a trend keenly felt by climate change researchers following the election of the Abbott Government (Holmes 2015). Don Weatherburn (2012), Director of the NSW Bureau of Crime Statistics and Research (BOCSAR), poses a significant question: "Why do governments trumpet the virtues of evidence-based policy, while often ignoring it in practice? One reason is that law and order policy is as much, if not more, influenced by what's popular than by what's effective.' What can be deduced from Sudmalis' use of the label 'minority' is that evidence-based research cuts across the popular manifestation of CCTV embedded deeply in the Liberal Party's discursive strategy, in which CCTV exists as a mechanism for the mobilisation of public support.

The powerful anti-crime 'dog-whistle' that comes with pro-CCTV discourse is entwined in the construction of local Liberal Party politicians' credibility and their public identities. Challenging these political commitments to CCTV with an evidence-based perspective is unlikely to sway their efforts. This was highlighted by Ward's fierce criticism of the Tribunal's decision on the Bonner case that found in favour of the proponent (Carr 2014a). These developments provide insight into the contemporary political context for a policy area that exists alongside a void of critical scrutiny regarding the funding of CCTV by government. They exemplify Garland's (2001: 133) observation that political actors are often 'concerned not so much with controlling crime as with expressing the anger and outrage that crime provokes'. In such circumstances, "policymaking becomes a form of acting out that downplays the complexities and longterm character of effective crime control in favour of the immediate gratifications of a more expressive alternative' (Garland 2001: 179). CCTV appears to be 'a policy solution that fits into a more general trend in crime-related policy - the privileging of immediate, visible political action over long-term strategies' (Galdon Clavell 2013: 196).

\section{Cultivating Consent: Comparisons With Ryde City Council}

The Safer Streets Programme can be viewed as a strategy to cultivate a hierarchy of perspectives within which local councils are compelled to comply with the federal government or forfeit the opportunity to attain grant monies. The first round of Safer Streets funding was 'only open to organisations who were invited by the Attorney-General's Department in May 2014 to apply for the delivery of specific commitments' (Australian Government-Attorney General's Department, Crime Prevention 2014). This funding was available 'by invitation only to nominated Councils to implement commitments announced during the 2013 election campaign' (Pears 2014). The first round of funding delivered 'almost \$20 million of projects across Australia. This includes: NSW \$6.45m; QLD \$5.89m; VIC \$3.09m; WA \$3.1m; SA $\$ 0.36 \mathrm{~m}$; NT \$0.30m' (Abbott and Keenan 2014). By early August 2014, in advance of the full list of councils that received Safer Streets funding being made publicly available by the Attorney's General Department, at least twelve Liberal MPs had announced successful funding recipients; and, all of the local councils that had been successful in attaining funding were located within federal electorates represented by Coalition MPs (Carr 2014b). ${ }^{7}$ Figures released by the Attorney-General's Department in early October

${ }^{7}$ Federal electorates/cities which received funding so far include Petrie/Moreton Bay Regional Council $(\$ 380,000)$; Durack/City of Geraldton (\$440,000); Dunkley/Frankston City Council, Mornington Peninsula Shire Council $(\$ 759,000)$; Deakin/Maroondah City Council and Whitehorse City Council $(\$ 680,000)$; Kooyong/City of 
2014 revealed that 90 per cent of first-round Safer Streets funding recipients-30 of the 34 grants approved - were in Coalition seats (Aston 2014).

The Abbott Government's CCTV funding scheme has been described as 'pork barrelling', which also explains why funding has purportedly been taken away from one local council previously allocated to it by the Labor Government in 2013 (Carr 2014b; Fitzgibbon 2014). A Sydney Morning Herald investigation uncovered further pork barrelling in September 2014 noting that 'Hundreds of millions of dollars in the Abbott government's Community Development Grants scheme have been tipped into projects in Coalition-held marginal seats in what Labor says is a return to the bad old days of electoral pork barrelling under the Howard government' (Kenny 2014a). From \$307 million allocated in the Community Development Grants program, \$257 million was directed to projects in Coalition electorates (Kenny 2014a).

The selective manner in which Safer Streets grants have been distributed effectively creates a patron-client scenario in which federal Coalition MPs are personally responsible for mediating the conditions in which federal funding is sought on a local council's behalf. These implications were demonstrated during Ryde City Council's meeting debate on $10^{\text {th }}$ June 2014 at which senior management confirmed that federal funds for CCTV could only be ascertained with the support of the federal Member (Ryde City Council 2014). Pressure on Ryde City Council to apply for CCTV funding began when the Liberal MP for Bennelong, John Alexander, circulated a petition to local businesses on $16^{\text {th }}$ May 2014. The Korean Chamber of Commerce presented it to the council requesting CCTV installations in Eastwood CBD (Carr 2014b). There had been a serious assault in May 2014 in Glen Reserve parkland-500 metres from Eastwood CBD - which 'led to requests for consideration of CCTV in that area as a deterrent and assistance to police in apprehending the offender' (Pears 2014). ${ }^{8}$

A report produced by Ryde Council's community safety officer recommended against installing CCTV in Eastwood CBD (Pears 2014). The report noted '[t]he Ryde Local Government Area has a relatively low crime rate for almost every major offence as reported in the March 2014 update of NSW Recorded Crime Statistics' (Pears 2014). It added: '[t]here is currently no evidence that Eastwood Town Centre would benefit from CCTV... This option is not recommended because the strategy would not address identified issues, is not recommended by the Police and would create a significant ongoing cost to Council' (Pears 2014). Ryde Councillors unanimously voted to seek funding for CCTV in Eastwood CBD via the office of the Member for Bennelong (Ryde City Council 2014), contradicting the recommendations produced by Ryde Council's community safety officer.

This scenario signifies the politicisation of the Safer Streets funding scheme which allows politicians to position themselves as the deliverers of community safety and cultivate support from local interest groups particularly business chambers. The structure of the Safer Streets scheme offers Coalition MPs significant opportunity for cultivating endorsement of Federal Government ideology in local communities. Coalition MPs personally control access to Safer Streets funding while making the delivery of the grants contingent upon acceptance of the Federal Government's policy and all of the assumptions implicit in it. Local

Boroondara (\$100,000); Canning/City of Mandurah (\$250,000); Forde/Logan City Council (\$960,000); New England/Tamworth Regional Council (\$500,000); Macarthur/Campbelltown City Council (\$350,000); Riverina/City of Wagga Wagga $(\$ 500,000)$; Paterson/Port Stephens Council $(\$ 52,000)$; and Gilmore/Kiama Municipal Council $(\$ 150,000)$.

8 The spouse and daughter of the victim addressed Councillors at the $10^{\text {th }}$ June Ryde Council meeting with an emotional plea and the specific request to apply for the funding to install CCTV. The speakers described how, following an impression given to the family by NSW Police, Ryde City Council's refusal to install CCTV was effectively responsible for the family's sense of injustice: 'the police couldn't do anything [...] they couldn't find any information because, they told me, because your Ryde Council didn't install the CCTV for them... [the police have] no lead[s] whatsoever' (Ryde City Council 2014). 
councils are invariably required to acquiesce Coalition propaganda which depicts CCTV spending as an 'obvious' solution, as normative, and the presumption that the Abbott Government's policy is 'common sense' (Carr 2014b; Coleman 2013; Palmer et al. 2012: 295). Federal funding for local council street cameras as a 'safer city' strategy is part of a broader economic project aimed at cultivating acceptance by local communities of the importance of a compliant public space during the transformation of urban centres into sites of 'neoliberal discursive production' (Peck and Tickell 2002: 380).

\section{Non-evidence Based and Virtually Unchecked: Why Evaluations Aren't Wanted}

CCTV is a mechanism allowing government to facilitate the flow of public funds to private companies through arrangements that are virtually unchecked and non-evidence based. Local councils that have implemented CCTV programmes in Australia have rarely produced any meaningful or substantial reporting and evidenced-based evaluations (Carr 2014a). Only one local council out of 18 surveyed in a national study had collected crime statistics within the surveillance area-namely, Shoalhaven City Council (Carr 2014a). Here, crime rates actually increased after cameras were installed, defying the logic of proponents such as Ward. In this sense crime statistics can be problematic for proponents of street cameras as a policy solution. Alternative interpretations might explain the rise in Shoalhaven's crime rate by suggesting that crime patterns may not have changed but simply been identified more through the street camera lens and reported by police (Welsh and Farrington 2002: 24). For proponents of street cameras this infers subscribing to two paradoxical scenarios: that, street cameras both decrease and increase crime rates. For politicians such a paradox offers opportunities: in terms of forming hegemonic 'strategies for securing stronger consensus', political success requires flexibility and assuming a position that maximises authority and notoriety (Briggs and Dearman 2005: 4). The effects of CCTV can be measured, moreover, beyond statistics. One impact of CCTV is crime displacement although this appears limited to certain crime categories (Gill and Spriggs 2005; Chainey 1999; Squires 1998). Among the impacts of CCTV are the financial and social costs; one national survey indicates that the shortcomings of CCTV for local councils are 'many and do not match the cost to install, monitor and maintain' (Carr 2014a: 8).

The potential for being discredited by objective evidence may explain why there is no strong desire expressed by politicians for local councils to produce regular CCTV evaluations. Notably, the Safer Streets Programme prohibits local councils from using CCTV funding for evaluations in the first round of funding. Funding can only be used for 'projects relating to specific commitments that support security enhancements such as better lighting, closed-circuit television (CCTV) and mobile CCTV in local crime hot spots' (Australian Government-Attorney General's Department, Crime Prevention 2014). ${ }^{9}$ Rogers' (2013) description of regulatory 'experimentation' is useful for rationalising why government has not prioritised evidentiary support in the distribution of street camera funding. He states: 'Regulatory experimentation may enhance the resiliency of organisations and infrastructure... [but] when standards and benchmarks seek to create "resilient subjects" and "resilient communities" the positive potential is lost in bureaucratic inflexibility' (Rogers 2013: 383). From this perspective oversight requirements nominally attached to government funding for street cameras - such as privacy regulations and evidencebased planning - can be construed as a barrier to the institutional resilience of local government pending the level of commitment by local councils towards business growth.

Without the level of accountability provided through evidence-based CCTV evaluations local councils are exposed to the risk of diminished credibility and independence from police (Carr 2014a). This is

9 The wording is vague in describing eligibility under the second round of funding, stating that funds will be available for 'the purchase of and installation of CCTV and other security related infrastructure [and] projects that target anti-social and unlawful behaviour' (Australian Government-Attorney General's Department, Crime Prevention 2014). The Safer Streets funding guidelines do however state that councils must provide to the Attorney General's Department an evaluation of 'the anticipated benefits' as set out in the initial funding proposal. 
particularly the case as local councils are increasingly held to ransom by commercial media working to galvanise the attentions of the public which often perceives crime to be 'out of control' even when it has significantly declined (Carr 2014a; Palmer et al. 2012; Smethurst 2013; Channel Ten News 2011; Weber 2011). Within such a context the 'fear of crime' is given as a primary justification for federal CCTV funding and the phrase is enshrined in the NSW Government's and many local council CCTV policies (NSW Attorney General's Department 2000; Australian Government n.d. a). This scenario highlights why CCTV funding for local governments is a populist response to largely unfounded fears.

CCTV evaluations are 'ultimately irrelevant' to politicians (Taylor 2010). As Galdon Clavell (2013: 195) states: 'videosurveillance as a policy solution in urban areas has less to do with its effectiveness in reducing crime than with its multifunctionality, which allows all actors involved (elected officials, the police, civil society organisations, etc.) to develop legitimisation arguments that fit their own agendas and logics'. It is within such a context that politicians have ignored research findings in statements about the Kiama and Ryde CCTV programmes. Galdon Clavell (2013: 198) concluded similarly: 'Any investment in technology is thus seen as a good investment, regardless of its cost or impact, which are never evaluated... [In Spain] those responsible for CCTV proliferation have never commissioned evaluations of any of the schemes installed'.

\section{Good Copy for News Media: Profitable Opportunities Beyond the Security Industry}

CCTV can be viewed as a mechanism through which government has facilitated profitable opportunities in and beyond the security technologies industry. Scholarship on street cameras in Australia is yet to explore the complexities of power relations incorporating not only how CCTV is used but who it is used by; the different contexts in which it is used; and, whether the reasons for its use include conveying political messages beyond the local communities from which footage is recorded and streamed. A broader understanding of the political economy of CCTV in Australia is required that accounts for 'which aspects of people's everyday lives are exposed, monitored, recorded and manipulated by multiple surveillance practices, all sharing the aim of extracting some value from such activity', be it commercial, political or social opportunities (Harper et al. 2013: 178; Ball 2002, 2009).

Exhibiting this point, commercial media frequently reproduces CCTV footage. Fairfax's The Illawarra Mercury, for instance, has published CCTV footage of crime in Wollongong on many occasions since Wollongong City Council installed its federally funded CCTV system in 2007 (Carr 2014a). This has significant implications for the ways in which the 'need' for CCTV in Kiama has been portrayed by politicians. As a conduit conveying the political and economic meanings affixed to street camera footage, news media in contemporary Australia plays a 'pivotal role[...] in projecting a hyper-real and multidirectional spectacle of events' (Pieri 2014: 39). Wollongong's CCTV footage has been appropriated into commercial news formats that have tended to present images of the Illawarra region as 'dark' and 'dangerous' (Carr 2014a). Commercially streamed crime footage has worked to reproduce tabloid discourses with regards to community perceptions of the Illawarra as 'unsafe' (Shields 2012).

In one example, in May 2014 Fairfax Media published CCTV footage of refugee Tumezgi Tesfay being assaulted in Wollongong (Tonkin 2014; Butler 2014). These images were syndicated from coverage in the Illawarra Mercury to the national Fairfax Media network and flanked by advertising for health insurance company 'Bupa' (see Image 7). The video footage 'shocked' media consumers and was a major coup for Fairfax, which produced at least five articles in the Illawarra Mercury that galvanised and capitalised on public outrage as evidenced in online reader comments posted underneath these articles. Through multimedia platforms, which incorporate social media functions and spaces for public comments online, the marketing of CCTV footage by news companies has been 'performed and configured by drawing consumers into a series of interrelated "commercial" activities' (Pridmore 2013: 107). As Pridmore (2013: 107) says, 'we are seeing a collaborative surveillance with specific implications for consumers, 
corporations and market practices', and as such 'much of what occurs in these contexts blurs the "natural" boundaries between the surveilled and the surveillors'. Jewkes (2004: 56) notes that 'real' footage from CCTV cameras is increasingly used in media to 'visually highlight the event's immediacy and authenticity'. While news media have increasingly incorporated street camera footage as a normative feature of news formats, little research has been published examining the regulation of Australian media organisations' use of surveillance techniques and technologies (Clarke 2014: 90).

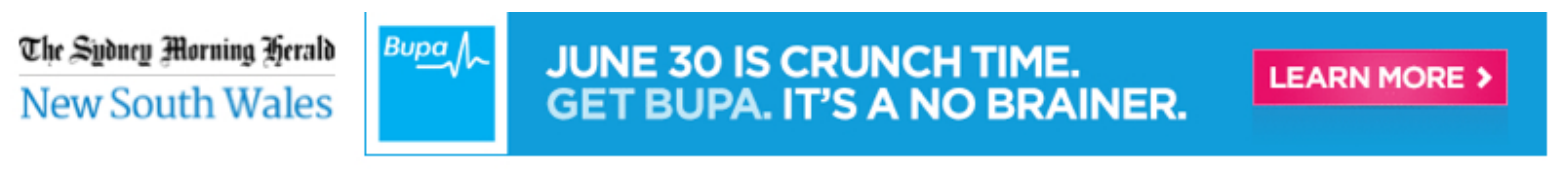

\begin{tabular}{l|l|l|l|}
\hline NSW News & Morning Express Education Health Environment Sydney Traffic Cars Jobs Real Estate Dating \\
You are here: Home s NSW & Search here... \\
\hline
\end{tabular}

\section{Timothy Williams jailed for violent robbery of refugee in Wollongong}
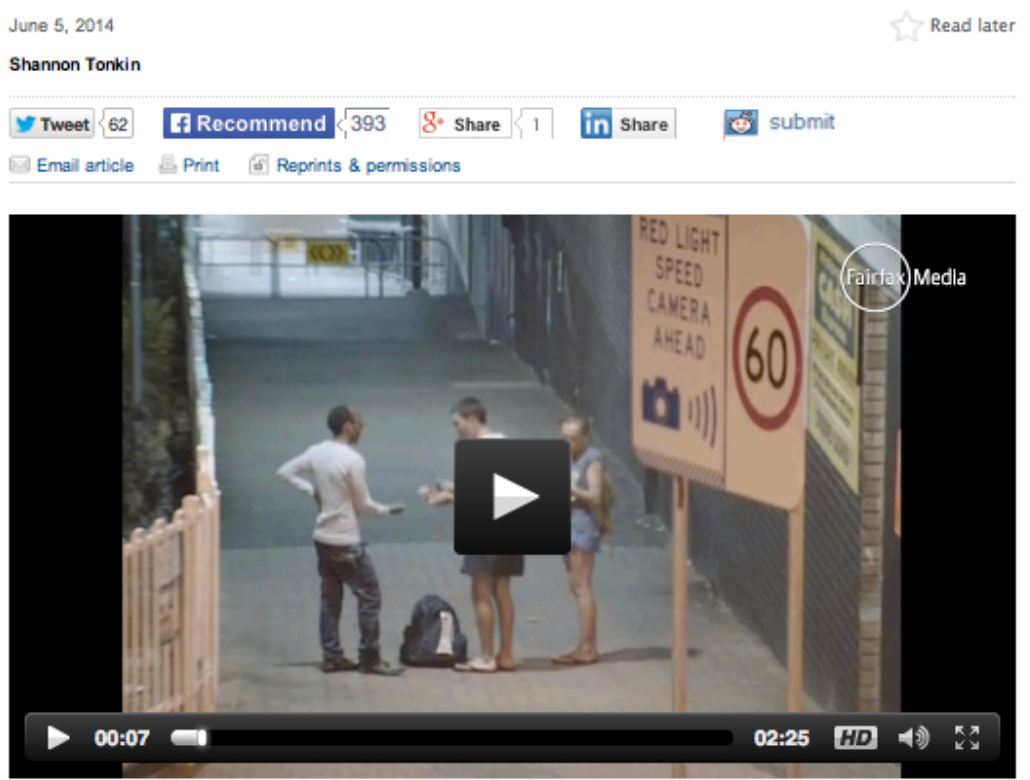

Advertisement

Autoplay ON OFF Video feedback Video settings

Refugee robbed and assaulted in Wollongong

Timothy Williams has been jailed for nine years for a "sickening attack" on a refugee who had only been in Australia for five days.

Image 7: Screenshot of Fairfax Media's Sydney Morning Herald online edition, 5th June 2014.

\section{CCTV Discourse and Institutionalisation as Normative}

CCTV can be viewed as a mechanism for reproducing political and social hegemony by working to normalise these relations at the level of discourse. Public debate in Australia is routinely galvanised by popular symbolism surrounding surveillance technology. Evidence presented in this article indicates that the providers of the technology (the state) and beneficiaries of it, such as commercial media, have invested significant resources in terms of mediating the meanings affiliated with the images captured on CCTV. This has had political and commercial implications and generated community expectations of local governments to perform surveillance roles. 
Popular discourse has been a significant barrier to rationalising CCTV in lieu of the need for rational planning and cost-effective policy (Palmer et al. 2012: 296). It has been potent in undermining informed perspectives in policy debate that might function as a check on populism and as 'a form of watching the powerful' as they engage in neo-liberal spatial politics and practices (Coleman 2013: 143). The reproduction of discursive hegemony involves determining 'ways of seeing and doing', and standardising practices so as to perpetuate the interests and voices of certain social and political actors; that is, determining ways of 'knowing, governing, predicting and controlling' (Ball and Snider 2013: 6). Noted elsewhere is that surveillance discourses do not merely react to 'crime'; they create 'truth regimes and constructs target populations' (Coleman and McCahill 2010: 228; Ball and Snider 2013: 3). Surveillance practices have historically functioned to make certain populations more visible and distinguish them from 'law abiding' citizens, singling them out for particular moral and legal sanctions (Ball and Snider 2013: $3)$.

In Australia a potent binary logic has been hegemonic within public debate concerning local council CCTV (Palmer et al. 2012: 296). Binary ploys surrounding CCTV are effective because they insist 'on the polarisation of the subject and provides communal comfort in removing ambivalence through the forced choice of either/or' (Pickering 2001: 172). It has tended to be these kinds of punitive binaries that have come to inform responses by the state, which in turn advocate the need to combat deviance as the foremost goal (Pickering 2001: 172). Discursive binaries are frequently used to dispel criticisms and evidence that contradicts the idea that CCTV is a useful crime prevention measure. Evidence of binary jargon at work can be viewed in the Member for Kiama's oft-stated phrase: 'If you have nothing to fear, you have nothing to hide' (Ward 2014). Members of the public commenting on media articles online frequently echo this phrase and the popular instinct has been to 'fall into line' or risk being viewed as a criminal 'other' with 'something to hide'. This binary mechanism is further evident in the notion of 'deter and detect' in which the normative presupposition is that, even if CCTV doesn't deter crime, it can still be used to detect it retrospectively. Within such logic CCTV is easily legitimated as a 'just in case' measure - if for no other reason, because of an implied dog-whistle that is sustained by the rhetorical ploy of 'who can really argue with that?' These kinds of discursive ploys have been used effectively to remove doubters and objective evidence from the public debate-even to the point at which civil liberties and privacy concerns have been labelled 'dangerous' by major news media (ABC 2013; Carr 2014a). The production of popular discourse in favour of state-sponsored street cameras has been undertaken alongside attempts by powerful state actors to naturalise and make popular the links between 'criminal' or 'deviant' behaviours and insubordinates (Hall et al. 1978; Kroener 2013: 122). Though speaking of the Australian Government's metadata retention laws enacted by federal parliament in 2015, Edward Snowden is skeptical of the 'nothing to hide/fear' logic, stating 'people who say they don't worry about their privacy because they have nothing to hide "is like saying I don't care about free speech because I have nothing to say" (Snowden, cited in Milman 2015). These metadata retention laws have opened a new frontier for public debate on the limits to individual privacy, although the role of discourse remains fundamental for proponents of the surveillance state as a legitimising component (Murakami Wood and Wright 2015; Keiber 2015: 168; Schultze 2015).

CCTV plays an increasingly important role as a component of institutionalised discourse, and the existence and acceptance of CCTV has in many ways become part the contemporary institutional experience internationally. Schools have installed CCTV to collect personal information of minors, the social implications of which have been explored by Taylor (2013). Brucato (2013: 158) further examined how 'new accountability' management policies are 'transformed into surveillance practices' in universities. Revealed by one Australian study is the existence of oppositional tensions in the bureaucratic language surrounding CCTV in local councils: ordinary council staff were much more critical of the effectiveness and usefulness of CCTV, whereas senior council management almost unanimously expressed a supportive view (Carr 2014a). This bureaucratic dynamic reflects how CCTV is often readily taken up as a kind of 'automatic' solution to crime by those in positions of authority while 'on the 
ground' knowledge and critical expertise are disregarded.

\section{Conclusion}

The politics of CCTV dissemination in Australia, intertwined with the imperatives of electoral success and commercial opportunity, is indicative of international trends with regards to the function that street cameras perform in the discourses and political economy of the state. While international comparisons are not core to the analysis in this article, the model I have utilised to explain the political economy of CCTV as a governmental policy may be useful in terms of conceptualising the proliferation of street cameras internationally. This is particularly in terms of advancing knowledge of localised political dynamics and accentuating key continuities and divergences within existing scholarship.

The installation of CCTV in Kiama reflects similarly upon the experiences of other local councils in Australia that have established street camera systems while facing political pressures cultivated by higher levels of government. Kiama's experience echoes urban makeover trends internationally with regards to the political and commercial advantages of cultivating public support for street camera schemes. Exploring the Safer Streets Programme, this article identified several components that underscore the political economy of surveillance in Australia. This includes conceptualising CCTV as: a component in the cultivation of stronger consensual relations between the federal government and local councils/communities; a mechanism for government to facilitate the flow of public funds to private companies through arrangements that are virtually unchecked and non-evidence based; a mechanism for government to facilitate profitable opportunities in and beyond the security technologies industry; and, a mechanism for reproducing hegemony by normalising these relations in discourse. Evident is that the meanings and interpretations surrounding local council CCTV footage are proactively mediated by hegemonic political and commercial actors in Australia. Further research may provide greater insight into the permeation of these meanings into social and institutional practice and their relationship with the cultivation of consent.

\section{References}

Abbott, T. and M. Keenan. 2014. "Delivering \$6.4 Million For Safer Streets in NSW" (Media Release, Department of Prime Minister and Cabinet and Department of Justice). 23 May. Accessed 4 September 2014. https://www.liberal.org.au/latest-news/2014/05/23/delivering-64-million-safer-streets-new-south-wales

Anderson, J. and A. McAtamney. 2011. "Considering local context when evaluating a closed circuit television system in public spaces." Trends \& Issues in Crime and Criminal Justice No.430, 421-440. Canberra: Australian Institute of Criminology. October.

Anderson, P. 2013. "Jill Meagher's mobile phone proved the vital clue for police tracking down accused Adrian Ernest Bayley". Herald-Sun. 13 March. Accessed 5 June 2014. http://www.heraldsun.com.au/news/law-order/jill-meaghers-mobilephone-proved-the-vital-clue-for-police-tracking-down-accused-adrian-ernest-bayley/story-fnat79vb-1226596495389.

Arnold, A. 2013. "Urgent review after CCTV shutdown”. Illawarra Mercury. 6 May. Accessed 8 May 2013. http://www.illawarramercury.com.au/story/1479381/urgent-review-after-council-cctv-shutdown/.

Arnold, A. 2014a. “Kiama’s Rusty Daisy Cow To Be Cloned”. Illawarra Mercury, 2 February. Accessed 8 May 2014. http://www.illawarramercury.com.au/story/2061154/kiamas-rusty-daisy-cow-to-be-cloned/

Arnold, A. 2014b. "CCTV Cameras to be Placed Around CBD”. Illawarra Mercury, 19 May. Accessed 8 May 2014. http://www.illawarramercury.com.au/story/2292453/cctv-cameras-to-be-placed-around-kiama-cbd/.

Aston, H. 2014. "Anti-crime prevention funds mostly allocated to Coalition electorates". Sydney Morning Herald. 5 October. Accessed 29 April 2015. http://www.smh.com.au/federal-politics/political-news/anticrime-prevention-funds-mostlyallocated-to-coalition-electorates-20141004-10q9nh.html.

Australian Broadcasting Corporation (ABC). 2013. "News - New South Wales." 7pm edition. 4 May.

Australian Government. 2012. "Graffiti prevention, reduction and/or removal funding 2012”. Canberra. Accessed 29 July 2013. http://www.crimeprevention.gov.au/POCAfundingfornongovernmentsgencies/Pages/default.aspx.

Australian Government. n.d. a. "National Community Crime Prevention Programme”. Accessed 31 March 2016. https://www.ag.gov.au/CrimeAndCorruption/CrimePrevention/Pages/NationalCommunityCrimePreventionProgramme. aspx.

Australian Government. n.d. b. “Organisations Funded under the 2007 Safer Suburbs Program”. Accessed 29 July 2013. http://www.crimeprevention.gov.au/Documents/Organisations Funded under the Safer Suburbs Program.pdf.

Australian Government. n.d. c. "National Community Crime Prevention Programme (NCCPP) Funded Projects". Accessed 31 
March 2016.

https://www.ag.gov.au/CrimeAndCorruption/CrimePrevention/Documents/NCCPP\%20Funded\%20Projects.pdf

Australian Government-Attorney General's Department, Crime Prevention. 2014. "Safer Streets Programme". Accessed 20 August 2014. http://www.crimeprevention.gov.au/Pages/default.aspx.

Australian Heritage Database. 2014. "Kiama Post Office”. Australian Government, Dept. of Heritage. Accessed 10 May 2014. http://www.environment.gov.au/cgibin/ahdb/search.pl?mode=place detail;search=state $\% 3$ DNSW $\% 3$ Blist code $\% 3$ DCHL $\% 3$ Blegal status $\% 3$ D35\%3Bkey word PD\%3D0\%3Bkeyword SS\%3D0\%3Bkeyword PH\%3D0;place id=105508.

Australian Security Industry Association Limited (ASIAL). 2014. "Security Industry Statistics, Estimated expenditure on private security in Australia, 2012-2013”. Accessed 4 September 2014. http://www.asial.com.au/resources/research-andstatistics.

Ball, K.S. 2002. "Elements of surveillance: A new framework and future directions." Information, Communication and Society 5(4): 573-590.

Ball, K.S. 2009. "Exposure.” Information, Communication and Society 12: 639-657.

Ball, K.S. and L. Snider. eds. 2013. Surveillance-Industrial Complex: A political economy of surveillance. Abingdon: Routledge. Briggs, R. and P. Dearman. 2005. "The Question of Consent Today". Southern Review 37(3): 1-7.

Brucato, B. 2013. "From accountability policy to surveillance practices in higher education”. In Surveillance-Industrial Complex: A political economy of surveillance, edited by K.S. Ball and L. Snider, 158-174. Abingdon: Routledge.

Butler, J. 2014. “Typical Wollongong? That's not the city I know.” Illawarra Mercury. 3 July. Accessed 10 August 2014. http://www.illawarramercury.com.au/story/2394691/typical-wollongong-thats-not-the-city-i-know/.

Byron Shire Council. 2015. "CCTV for Byron Bay town centre" (Media Release). 15 July. Accessed 2 September 2015. http://www.byron.nsw.gov.au/media-releases/2015/06/15/cctv-for-byron-bay-town-centre.

Carr, R. 2014a. "Surveillance Politics and Local Government: A National Survey of Federal Funding for CCTV in Australia". Security Journal. March. DOI: 10.1057/sj.2014.12.

Carr, R. 2014b. "Singular Vision: CCTV Installation for crime prevention, or 'friends of the government'?” The Saturday Paper. 2 August. Accessed 2 August 2014. http://www.thesaturdaypaper.com.au/news/politics/2014/08/02/cctv-installationcrime-prevention-or-friends-the-government/1406901600\#.U qavihibvz

Cetinski, D. 2013. “CCTV Election Carrot”. Kiama Independent. 2 September. Accessed 5 February 2014. www.kiamaindependent.com.au/story/1747238/cctv-election-carrot.

Chainey, S. 1999. "Crime Mapping Case Studies Volume 2: successes in the field”. Washington DC: United States Institute of Justice.

Channel Ten News. 2011. "Out of Control”. 17 February. Accessed 8 August 2013. http://www.youtube.com/watch?v=191KCHQhEMQ\&feature=related

Clarke, R. 2014. "Surveillance by the Australian Media, and Its Regulation”. Surveillance \& Society 12(1): 89-107.

Coaffee, J. and P. Rogers, 2008. "Reputational risk and resiliency: The branding of security in place-making". Place Branding and Public Diplomacy 4: 205-217.

Coleman, R. 2004. "Watching the Degenerate: Street Camera Surveillance and Urban Regeneration”. Local Economy August 19(3): 199-211.

Coleman, R. 2013. "The imagined city: power, mystification and synoptic surveillance”. In Surveillance-Industrial Complex: A political economy of surveillance, edited by K.S. Ball and L. Snider, 141-157. Abingdon: Routledge.

Coleman, R. and M. McCahill. 2010. Surveillance and Crime. London: Sage.

Cook, R. 2014. "The people versus the political class". The Monthly. June. http://www.themonthly.com.au/issue/2014/june/1401544800/richard-cooke/people-versus-political-class.

Crabb, B. 2014a. "CCTV proposal well supported”. Kiama Independent. 7 April. Accessed 10 August 2014. http://www.kiamaindependent.com.au/story/2202593/cctv-proposal-well-supported/.

Crabb, B. 2014b. "Crime figures down but beware of complacency". Kiama Independent. 21 April. Accessed 10 August 2014. http://www.kiamaindependent.com.au/story/2231246/crime-figures-down-but-beware-of-complacency/.

Fitzgibbon, J. 2014. "Maitland's CCTV Funding Should Be On Need Not Political Partisanship" (Media Release, Federal Member for Hunter, Shadow Minister for Agriculture and Rural Affairs). 16 June. Accessed 30 July 2014. http://www.joelfitzgibbon.com/media/maitland's-cctv-funding-should-be-on-need-not-poli/.

Foucault, M. 1980. “The eye of power.” In Power/Knowledge: Selected Interviews and Other Writings 1972-1977 by Michel Foucault, edited by C. Gordon, 146-165. Sussex: Harvester Press.

Fussey, P. 2007. "An Interrupted Transmission: Processes of CCTV implementation and the impact of human agency". Surveillance \& Society 4(3): 229-256.

Fussey, P. 2004. "New Labour and New Surveillance: Theoretical and political ramifications of CCTV implementation in the UK". Surveillance \& Society 2 (2/3): 251-269.

Galdon Clavell, G. 2011. "The Political Economy of Surveillance in the (Wannabe) Global City (Opinion)”. Surveillance \& Society 8(4): 523-526.

Galdon Clavell, G. 2013. "CCTV in Barcelona: the political economy of surveillance in the (wannabe) global city." In Surveillance-Industrial Complex: A political economy of surveillance, edited by K.S. Ball and L. Snider, 191-207. Abingdon: Routledge.

Garland, D. 2001. The Culture of Control: Crime and Social Order in Contemporary Society. Oxford: Oxford University Press. 
Germain, S. 2013. “A prosperous 'business': The success of CCTV through the eyes of international literature.” Surveillance \& Society 11(1/2): 134-147.

Gill, M. and Spriggs, A. 2005. “Assessing the impact of CCTV. Home Office Research Study 292”. London: Home Office. GPT Group. 2015. "Our Business - Overview”. Accessed 26 March 2015. http://www.gpt.com.au/Our-Business/Overview.

Haggerty, K.D. and R.V. Ericson. 2000. “The surveillant assemblage”. British Journal of Sociology 51(4) (December): 605-622.

Hall, D. 2015. "Kiama CCTV switch on slated for March.” Kiama Independent. 17 February. Accessed 11 May 2015. http://www.kiamaindependent.com.au/story/2889367/eyes-on-kiama-not-far-off/.

Hall, S., C. Critcher, T. Jefferson, J. Clarke and B. Roberts. 1978. Policing The Crisis: Mugging, the State and Law and Order. London: Macmillan.

Harper, D., I. Tucker and D. Ellis. 2013. "Surveillance and subjectivity: everyday experiences of surveillance practices.” In Surveillance-Industrial Complex: A political economy of surveillance, edited by K.S. Ball and L. Snider, 175-190. Abingdon: Routledge.

Hasselberg, I. 2014. "Coerced to Leave: Punishment and the Surveillance of Foreign-National Offenders in the UK." Surveillance \& Society 12(4): 471-484.

Hier, S.P. 2003. "Probing the Surveillant Assemblage: on the dialectics of surveillance practices as processes of social control." Surveillance \& Society 1(3): 399-411.

Holmes. D. 2015. “The Bjorn supremacy - is Australia getting the climate change advice it deserves?" The Conversation. 23 April. Accessed 11 May 2015. https://theconversation.com/columns/david-holmes-84799.

Jewkes, Y. 2004. Media and Crime. London: Sage

Keiber, J. 2015. "Surveillance Hegemony." Surveillance \& Society 13(2): 168-181.

Keval, H. and M.A. Sasse. 2010. "Not the usual suspects': A study of factors reducing the effectiveness of CCTV.” Security Journal 23(2): 134-154.

Kenny, M. 2014a. "Coalition's 'regional rorts' make a comeback, says Labor.” Sydney Morning Herald. 29 August. Accessed 30 July 2014. http://www.smh.com.au/federal-politics/political-news/coalitions-regional-rorts-make-a-comeback-sayslabor-20140828-109o7y.html.

Kenny, M. 2014b. “Auditor-General to examine Abbott government's anti-crime fund over pork-barrelling claims”. Sydney Morning Herald, 1 September. Accessed 29 April 2015. http://www.smh.com.au/federal-politics/politicalnews/auditorgeneral-to-examine-abbott-governments-anticrime-fund-over-porkbarrelling-claims-2014083110al2q.html.

Kiama Municipal Council. 2014. “Kiama CBD Street Safety CCTV Project: We Want Your Feedback!” (Report). Accessed 21 July 2014. http://www.google.com.au/url?sa=t\&rct=j\&q=kiama council cctv we want your feedback\&source=web\&cd=1\&ved=0CBwQFjAA\&url=http $\% 3 \mathrm{~A} \% 2 \mathrm{~F} \% 2 \mathrm{Fwww} \cdot$ kiama.nsw.gov.au $\% 2 \mathrm{FArticleDocume}$ nts\%2F901\%2FReport\%20Summary.pdf.aspx\&ei=CXOjU6D2ItGE8gWHjYKIBQ\&usg=AFQjCNGDgslcK5KaEFIN2 A58nLiN DjdIQ\&sig2=g4ZGyvJszDhyKpnLS5Kfug\&bvm=bv.69411363,d.dGc.

Kiama Tourism. 2012. "Kiama, South Coast NSW.” Accessed 30 June 2014. http://www.kiama.com.au/.

Knight, B.A. 2000. "Watch me! Webcams and the public exposure of private lives". Art Journal 59(4): 21-25.

Koskela, H. 2003. "“Cam-era' - the contemporary urban Panopticon.” Surveillance \& Society 1(3): 292-313.

Koskela, H. 2006. "'The other side of surveillance': webcams, power and agency." Theorizing Surveillance: the panopticon and beyond, edited by D. Lyon, 163-181. Routledge: Milton Park.

Kroener, I. 2013. "“Caught on Camera': The Media Representation of Video Surveillance in Relation to the 2005 London Underground Bombings.” Surveillance \& Society 11(1/2): 121-133.

Illawarra Regional Information Service (IRIS). 2013. "Kiama.” January. Accessed 30 July 2014. http://www.iris.org.au/index.pl?page=223.

Lyon, D. 2001. Surveillance Society: Monitoring Everyday Life (Issues in Society). Phildelphia: Open University. McCahill, M. 2002. The Surveillance Web: The rise of visual surveillance in an English city. Cullompton: Willan.

Milman, O. 2015. "Edward Snowden says Australia's new data retention laws are 'dangerous". The Guardian. 9 May. Accessed 13 May 2015. http://www.theguardian.com/us-news/2015/may/09/edward-snowden-says-australias-new-data-retentionlaws-are-dangerous.

Murakami Wood, D. and S. Wright. 2015. "Editorial: Before and After Snowden.” Surveillance \& Society 13(2): $132-138$.

New South Wales Attorney General's Department, Crime Prevention Division. 2000. "NSW government policy statement and guidelines for the establishment and implementation of closed circuit television (CCTV) in public places." Sydney. Accessed 26 March 2015. http://www.lawlink.nsw.gov.au/lawlink/cpd/1l cpd.nsf/vwFiles/cctv.pdf/\$file/cctv.pdf.

New South Wales Bureau of Crime Statistics and Research (NSWBOCSAR). 2014. "NSW Recorded Crime Statistics 2009-2013 - Kiama”. Accessed 4 March 2015.

http://www.bocsar.nsw.gov.au/agdbasev7wr/ assets/bocsar/m716854110/kiamalga.xls.

Office of the Australian Information Commissioner. 2015. "Australian Privacy Principles". Australian Government: Canberra. Accessed 26 March 2015. http://www.oaic.gov.au/privacy/privacy-act/australian-privacy-principles.

Palmer, D., I. Warren and P. Miller. 2012. "ID Scanning, the Media and the Politics of Urban Surveillance in an Australian Regional City." Surveillance \& Society 9(3): 293-309.

Pears, L. 2014. "Late Item - Item 12: CCTV Cameras in Eastwood (Staff Report, Community Projects Officer - Roads and Community Safety)”. 10 June. Accessed 10 July 2014. http:/www.ryde.nsw.gov.au/files/assets/public/councilmeetings/2014/council-meeting-10-jun-2014-late-item-12.pdf?streamfile=true. 
Peck, J. and A. Tickell, 2002. "Neoliberalizing Space.” Antipode 34(3): 380-404.

Percy-Dove, L. 2014. "The Common Argument for Security Technologies.” Australian Security Magazine - Asia Pacific Security Magazine. June/July. Accessed 30 July 2014.

http://issuu.com/apsm/docs/print emag june july with links/41?e=9108448/8213138.

Pickering, S. 2001. "Common Sense and Original Deviancy: News Discourses and Asylum Seekers in Australia." Journal of Refugee Studies 14(2): 169-186.

Pieri, E. 2014. "Emergent policing practices: Operation Shop a Looter and urban space securitisation in the aftermath of the Manchester 2011 riots." Surveillance \& Society 12(1): 38-54.

Pridmore, J. “Collaborative surveillance: Configuring contemporary marketing practice”. In Surveillance-Industrial Complex: A political economy of surveillance, edited by K.S. Ball and L. Snider, 107-121. Abingdon: Routledge.

Rogers, P. 2013. "The Rigidity Trap in Global Resilience: Neoliberalisation Through Principles, Standards, and Benchmarks". Globalisations 10(3): 383-395.

Rose, N. 1999. Powers of Freedom; Reframing political thought. Cambridge: Cambridge University Press.

Ryde City Council. 2014. “Council Meeting 10 June 2014 Part 1 (USTREAM).” 10 June 2014. Accessed 30 July 2014. http://www.ustream.tv/recorded/48620416.

Shields, B. 2012. "Wollongong residents' negative view of city.” Illawarra Mercury. 20 May. Accessed 20 June 2013. http://www.illawarramercury.com.au/story/113330/wollongong-residents-negative-view-of-city/.

Schulze, M. 2015. "Patterns of Surveillance Legitimization: The German Discourse on the NSA Scandal." Surveillance \& Society 13(2): $197-217$

Smethurst, A. 2013. "Moreland council yet to accept $\$ 250000$ grant to install CCTV cameras in area where Jill Meagher was murdered." Herald-Sun. 25 April. Accessed 30 July 2014. http://www.heraldsun.com.au/news/law-order/morelandcouncil-yet-to-accept-250000-grant-to-install-cctv-cameras-in-area-where-jill-meagher-was-murdered/story-fnat79vb1226629442108 .

Stockland. 2015. "About Stockland”. Accessed 26 March 2015. http://www.stockland.com.au/about-stockland.htm.

Squires, P. 1998. "An Evaluation of the Ilford Town Centre CCTV Scheme”. Brighton: Health and Social Policy Research Centre, University of Brighton.

Sudmalis, A. 2014. "CCTV Actually Deters Crime” (Letter). Kiama Independent. 11 June, Accessed 12 June 2014. http://www.kiamaindependent.com.au/story/2339309/cctv-actually-deters-crime/?cs=1964.

Sunshine Coast Council. 2014. "Community Engagement Toolkit”. Accessed 30 July 2014. http://www.sunshinecoast.qld.gov.au/addfiles/documents/community/comm engage toolkit.pdf.

Taylor, E. 2010. "Evaluating CCTV: Why the findings are inconsistent, inconclusive and ultimately irrelevant." Crime Prevention and Community Safety 12(4): 209-232.

Taylor, E. 2011. "UK schools, CCTV and the Data Protection Act 1998." Journal of Education Policy 26(1): 1-15.

Taylor, E. 2013. Surveillance Schools: Security, Discipline and Control in Contemporary Education. Palgrave Pivot.

Tonkin, S. 2014. "Timothy Williams jailed for violent robbery of refugee in Wollongong". Sydney Morning Herald. 5 June. Accessed 6 June 2014. http://www.smh.com.au/nsw/timothy-williams-jailed-for-violent-robbery-of-refugee-inwollongong-20140605-39lzj.html.

Vaz, P. and F. Bruno. "Types of Self-Surveillance: from abnormality to individuals 'at risk'." Surveillance \& Society 1(3): 272291.

Victorian Law Reform Commission. 2010. "Surveillance in Public Places - Final Report 18". Melbourne: Government of Victoria. Accessed 26 March 2015. http://www.lawreform.vic.gov.au/sites/default/files/Surveillance final report.pdf.

Visit NSW. 2014. "Kiama.” Destination NSW, State Government of NSW. Accessed 30 June 2014. http://www.visitnsw.com/destinations/south-coast/kiama-area/kiama.

Ward, G. 2014. “CCTV Cameras Support Police (Letter).” Kiama Independent. 11 June. Accessed 12 June 2014. http://www.kiamaindependent.com.au/story/2354786/cctv-cameras-support-police/?cs=1964.

Weatherburn, D. 2012. "Effective law and order policy need not be a shot in the dark." The Sydney Morning Herald. 10 January. Accessed 30 July 2014. http://www.smh.com.au/opinion/politics/effective-law-and-order-policy-need-not-be-a-shot-inthe-dark-20120109-1 prpm.html\#ixzz1j306c4MA.

Weber, S. 2011. "A night out in Wollongong” (Media release by the Police Association of New South Wales). Better State. 18 February. Accessed 10 February 2012. http://betterstate.org.au/communitysafety/2011/02/18/a-night-out-inwollongong/.

Webster, W. 2009. "CCTV Policy in the UK: reconsidering the evidence base". Surveillance \& Society 6(1): 10-22.

Welsh, B.C. and D. Farrington. 2002. "Crime prevention effects of closed circuit television: a systematic review. Home Office Research Study 252”. London: Home Office Research, Development and Statistics Directorate.

Wilson, D. and A. Sutton. 2003. "Open-Street CCTV in Australia: A comparative study of establishment and operation". A Report to the Criminology Research Council. Accessed 26 March 2015. http://www.criminologyresearchcouncil.gov.au/reports/200102-26.pdf. 